Soner DOĞAN', Associate Professor, Phd

Department of Education Management, Faculty of Education

Sivas Cumhuriyet University

Sivas, Turkey
Original scientific paper

UDC: 37.058

DOI: $10.5937 /$ IstrPed2002417D

\title{
AS AN EDUCATIONALIST WORKING FOR A PUBLIC SCHOOL, WOULD YOU SEND YOUR CHILD TO A PRIVATE SCHOOL? PRIVATE SCHOOLS IN TURKEY
}

\begin{abstract}
The rapid increase in the number of the private schools in Turkey provides parents new choices. This also leads teachers and administrators who work for state schools and who are also parents themselves to make a choice between private schools and state schools. In this regard, the aim of this study is to review the opinions of teachers and administrators working for the state schools on private schools. The research method is qualitative phenomenology design. The study group involves a total 136 teachers and school administrators working in schools located in Sivas city centre. The data of the study is collected via a survey with open ended questions developed by the researcher. Content analysis method is used for the analysis, and the data are demonstrated with the graphics. As their positive opinions on private schools, teachers and administrators stated that private schools supports academic success, they are rich in physical environment, they have more extra-class activities, they provide convenience for working parents and they contribute to students' progress. However, their negative opinions are private school fees, not enough contribution to student progress, constant turnover of teachers, and misleading behaviours towards parents. The findings show that, comparatively, the teachers and administrators are more reluctant to send their children to private schools, and besides, they have more negative viewpoints on private schools. At the end of the study, the suggestions both by the participants and the researcher are included.
\end{abstract}

Keywords: private school; public school; teachers; school administrators; phenomenology design.

\section{INTRODUCTION}

Relying on the global changes and demands, education has been restructured in accordance with the neoliberal policies with the help of the international actors such as the World Bank (WB), International Monetary Fund (IMF), World Trade Organization (WTO), and General Agreement on Trade in Services (GATS) (Bayram, 2015). In this regard, the individuals' qualifications expected to be gained in the schools, which are the fundamental element of education, have become different (Uysal, 2017). Schools have been varied due to these changing trends and needs, and private schools have emerged as a part and result of this variety. Vandenberghe and Robin (2004) described private schools as being an institution

\footnotetext{
1'E-mail:snr312@gmail.com
} 
administered directly or indirectly by non-government organizations (such as churches, unions, trade or any other private organizations) in reference to the OECD sources. That's to say, the basic criteria are not financial sources, but legal status of the school institution.

Public school and privately financed schools are exist together in all educational systems (Bertola, Checchi and Oppedisano, 2007). Public (state) schools share similar missions as they have been structured by similar norms and values. However, private schools are differentiated by their school missions. Private schools' mission is to prepare students to a good life step by step by providing them credence (Boerema, 2006).

The main factor of the emergence and expanding of the private schools is the lack of performance by public schools in providing their students a good progress and development Alderman, Orazem and Paterno, 2001; Figlio and Stone, 2001; Chakrabarti, 2007; Narayan, 2010; Chudgar and Quin, 2012; Iqbal, 2012; Thapa, 2013). Although states provide free education to their citizens with the principle of equal opportunities, they are incapable of meeting the growing demand in education due to the shortages in public fundings. For this reason, parents with high incomes prefer private schools for more quality education (Bedi and Garg, 2000). In the recent years, as a result of the increase in the number of the private schools, the competition in this sector has also increased, and this has led to parents to become pickier about schools (Alpaykut, 2017).

Parents wishing to choose the best for their children often ask with the question of whether to send them to public schools or private schools (Pulat, 2019). Parents choose private schools for some alternative reasons such as their smaller learning environment, Montessori education approach, or academic achievement (Hall and Nattinger, 2012). Parents also choose private schools as they think they children would be bullied, or children special needs would not be met in state owned schools. When both parents work, the private schools are more preferable as they administer full-time schooling (Erakkus, Basoren ve Abimbola, 2016). Private schools are also able to provide a more quality education in terms of the quality of their teaching staff, school buildings, classrooms, and the quality of training services (Kulaksizoglu, Cakar ve Dilmac, 1999). The demands for the private schools are increasing gradually as parents wishing to prepare their children beginning with the young age for today's competitive environment because private schools provide more quality foreign language education, have less crowded classes, and have better physical environment (Paker ve Yarimoglu, 2015). Furthermore, it is known that in many countries, the students in private schools do better in international assessments than the ones in public schools (Sakellariou, 2017).

Private schools in Turkey, different from the traditional school perception, began to be established by foreign communities and minorities during the Tanzimat Reform Era, which is considered as the beginning of the westernization. The private schools of foreign communities and minorities have had positive impact on Turkish education system in its innovation and by enhancing its qualification. After the Republic, especially during the first years of the Republic, the schools of minorities were taken under the supervision and control of the state, and their activities were restricted. From the Establishment of the Republic (1923) to the 1960s, the development of the private schools were stable (Uygun, 2003). Financial tightness and difficulties in educational financing in Turkey formed the basis of the foundation and the development of the private educational institutions, and after the 1980s, these institutions gained speed in being established (Kulaksizoglu, Cakar and Dilmac, 1999). 
Particularly since the 2000s, private schools have become one of the popular institutions where parents would send their children thanks to governmental incentives and structural alterations in private teaching institutions (Bingolbali, 2018). Moreover, there have been a dramatic increase in the number of the private schools together with the closure of the private teaching institutions in 2014, and with their having been transformed into private schools (Aslan, 2019).

Today in every level of the Turkish education system, the existence of private schools sharing similar status with public schools brings about positive competition in education. Considering their history and their development in educational perceptions, it is clear that private schools are an indispensable part of education now, and will be in the future. Day by day, though they have some temporary problems, there has been a great interest in these schools, and accordingly, the number of these schools is increasing (Altay, 2018). Hence, according to National Education statistics (2018-2019), there are 12.809 schools providing education at the degrees of pre-school, primary education, and secondary education, along with 1.440 .577 students enrolled in Turkey. According to the Ministry of National Education (MNE), the proportion of the private school students to the total number of the students in Turkey is $16,50 \%$ in pre-school education; $5 \%$ in primary schools, $6,20 \%$ in secondary schools, and $13,70 \%$ in high schools (MEB, 2019).

In the literature, considering private schools in the Turkish education system, some notable studies are conducted about parents' choice and satisfaction (Hesapcioglu and Nohutcu, 1999; Keskin and Turna, 2010; Alpaygut, 2017; Uysal, 2017; Pulat, 2019), about teachers working in private schools (Aslan and Bakir, 2014; Onaran, 2018; Kolbasi, 2019; Kirbas, 2019), administrators working in private schools (Cankaya, Gun and Koleji, 2016; Erakkus, Basoren and Abimbola, 2016; Cimen and Karadag, 2019), private school businesses (Bayram, 2015; Ozdemir and Tuysuz, 2017), comparison of private schools and public schools (Cevik, 2005; Arslan, Satici and Kuru, 2006, 2007; Tasdan and Tiryaki, 2010; Celebi, 2009; Cobanoglu, 2011; Eryilmaz and Burgaz, 2011; Yavuz and Yilmaz, 2012; Ilgar, 2014; Oksuz, 2018).

The efficiency of both public and private schools has been a research subject in many studies on the fields of educational sciences, sociology, and economy not only in the United States, but also in Europe (Dronkers and Robert, 2008). When the international literature except Turkey is reviewed, there have been various studies about comparison of private and public schools (Bedi and Garg, 2000; Watkins, 2006; Bellei, 2007; Thapa, 2013; Deeba and Perveen, 2013; Sakellariou, 2017), about selection of private schools (Butler and Zanten, 2007; Valassi, 2009; Carpenter and Kafer, 2012; Sander, 2015), about the achievement in private schools (Chudgar and Quin, 2012), about transnational comparison of private schools (Vanderberghe and Robin, 2004), and about governmental incentives for private schools (Ferreyra, 2007; Cowen, 2010). As for this study, it is mainly about selection of schools and parents' satisfaction. However, it has some dissimilarities with the other studies as it includes viewpoints of both teachers and administrators working for public schools, and their evaluation of private schools as parents in these schools. With this study, it is aimed to contribute to the literature with the views of the teachers and administrators working for public schools about sending their children to private schools by using their identity as educationalists. 


\section{METHOD}

This section includes the methodology of the study. The research model, the study group, and the data collection tools of the study, and the analysis of the data are given in accordance with the aim of the study.

\section{Research Model}

This study is carried out in compliance with phenomenology design which is one of the qualitative research methods. Phenomenological studies focus on the core of the experiences. That is to say, the aim is to describe the core of phenomenon that has been experienced (Creswel, 2013). In this regard, with the increase in their numbers and their being part of the education system, private schools can be considered as a phenomenon affecting students, teachers, and parents directly. As a phenomenon, the roles of private schools in education system, their reasons to be selected, their positive and negative sides are all experienced by individuals. Thereby, it is concluded that private schools being a phenomenon concerning all segments of society can be described using phenomenological design.

\section{Study Group}

Cluster sampling method has been used while choosing the study group. When the population is divided into separate groups in cluster sampling, each group may have different representability. In this case, each group is represented equally in proportion to their number of elements (Sahin, 2012). In relation to that, the study group has comprised 6 primary schools, 6 secondary schools, and 6 high schools in Sivas city centre. While designating the study group, different levels of schools have been accepted as separate groups, thus each group has been provided to be represented equally. Following that, the survey developed by the researchers has been distributed to the schools. Volunteer participant teachers have been taken into account while handing out the surveys. As a result of the conduct of the survey, 36 administrators and 97 teachers' surveys have been evaluated.

\section{Data Collection Tool}

The data was collected via survey method. The survey form was developed by the researcher. The process of survey development comprises 4 steps. They are consecutively, defining the problem, item writing, getting experts' opinion, and implementing a pre-test (Anderson, 1990 as cited in Buyukozturk, 2005). The problem of this research is to analyse the phenomenon of private schools, which play a crucial role in Turkish education system and are having a rapid increase in number, according to the reviews of teachers and school administrators. During the item writing step, the related literature was reviewed, teachers and administrators having private school experience were interviewed, and survey questions were designed. On the third step, the field experts were consulted, and necessary changes were made. The pre-test was implemented to five teachers and five administrators who were not included in sampling group, and in accordance with the results of the pre-test, the survey form was finalized. Hereby, after the introduction about the survey, there are four questions in it. The questions are; a) Would you send your child to a private school? b) What are the positive sides of private schools? c) What are the negative sides of private schools? d) What are your suggestions on private school system? 


\section{Analysis of the Data}

Content analysis method was used in the study. In content analysis, inductive method is used. That is, the dataset is divided into smaller items and then coded; afterwards, theses codes helps us to get to categories, and eventually we get the themes (Yildirim and Simsek, 2011). Therefore, the dataset was transferred into computer by the researchers and they were coded there. With the help of these codes, categories and themes were obtained. The data obtained were presented via graphics in order to provide better understanding and better analysis of readers. The participant teachers were indicated with the symbols $\left(A_{1}, A_{2}, A_{3}, \ldots\right)$. $\left(\mathrm{T}_{1}, \mathrm{~T}_{2}, \mathrm{~T}_{3}, \ldots\right)$, and the participant administrators were indicated with the symbols $\left(\mathrm{A}_{1}, \mathrm{~A}_{2}, \mathrm{~A}_{3}\right.$, ...).

The validity and reliability of the study was provided upon the terms which were credibility, transmissibility, and confirmability which were stated by Mills (2003). For this reason, the research process has been put forward in detail. The development of the data collection tool took 4 steps, and each step was introduced elaborately. During the analysis process, the data were coded objectively and with great precision. In order to get reliable information, necessary explanation were made to the participants, and the survey was handed out the voluntary participants. So as to support the validity and reliability of the study, direct quotations from the participants were used to enrich the content. The data were examined by the researcher for the second time, and similar results were attained.

\section{FINDINGS}

The research findings have been examined under 8 themes. These themes are $a$ ) teachers' opinions on sending their children to private schools, $b$ ) teachers' positive opinions on private schools, c) teachers' negative opinions on private schools, d) teachers' suggestion about private schools, e) administrators' views on sending their children to private schools, $f$ ) administrators' positive opinions on private schools, g) administrators' negative opinions on private schools, $h$ ) administrators' suggestion about private schools. The findings related to the themes are presented with graphics.

Teachers' opinions on sending their children to private schools are given in Graphic 1. Graphic 1 includes six categories and a total of 86 codes.

\section{Graphic 1: Teachers' opinions on sending their children to private schools}

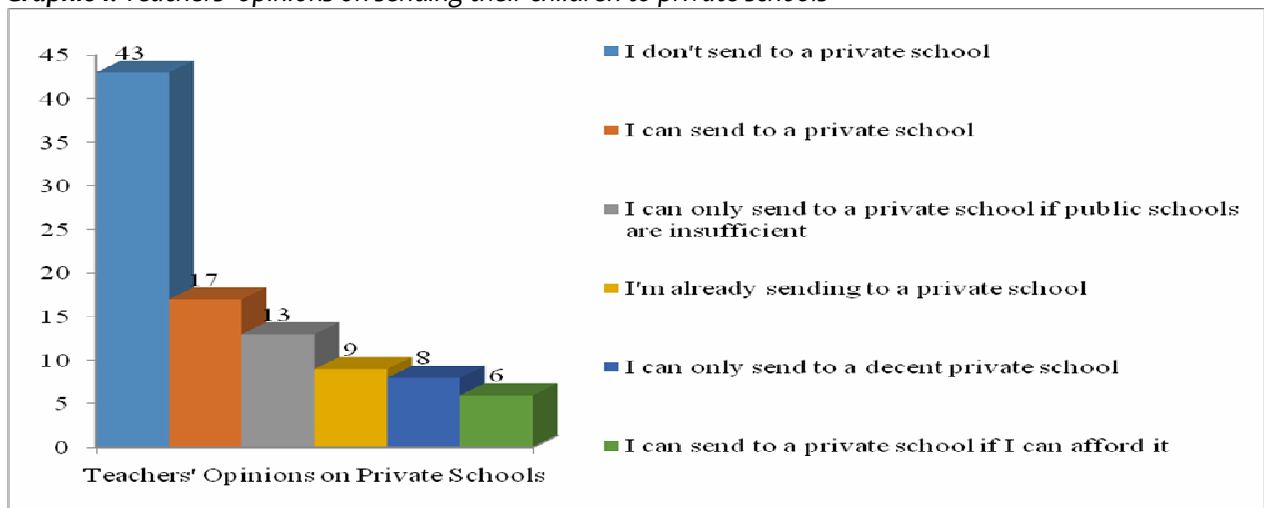


According to Graphic 1, half of the teachers stated that they would not send their children to private schools. 27 participants expressed that they needed some certain conditions to send their children to private schools. The number of the teachers who do not send their children to private school is considerably few comparing to those who already send their children to private schools. This indicates that most of the teachers have a negative attitude towards sending their children to private schools.

Teachers' positive opinions on private schools are given in Graphic 2. Graphic 2 includes five categories and 133 codes.

\section{Grafik 2: Teachers' positive opinions about private schools}
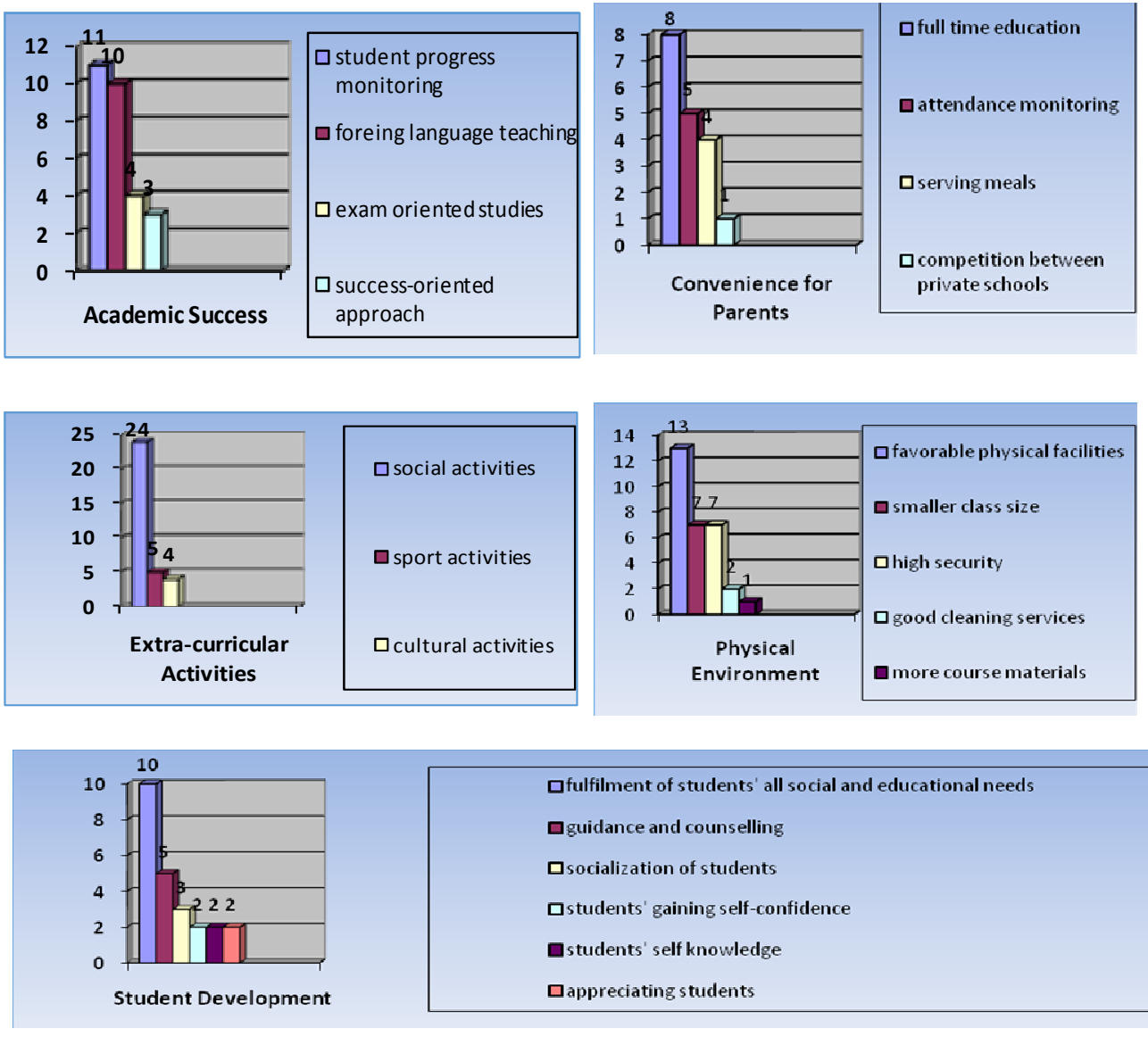

As it is pointed out in Graphic 2, the categories of academic success, physical environment, and student development stand out within the positive opinions of teachers on private schools. Students' progress monitoring and foreign language teaching under academic success category; favourable physical facilities and smaller class size under physical environment category; social activities and sport activities under extracurricular activities 
category; fulfilment of students' all social and educational needs and guidance and counselling under student development category are emphasized. Regardless of their mainly negative opinions on sending their children to private schools, Graphic 2 shows that teachers are well-informed about the advantages of private schools.

Some of the remarks by the participants are below:

"The advantage of private schools is that they ease the burden of parents. We don't have any worries about our children. The school meets educational and social needs with their activities" (T7).

"Yes, I would send. The busy working life requires children to be home alone. Private schools have advantages such as favourable start/finish times with working hours, smaller class size, intensive social activities, caring students closely" (T39).

Teachers' negative opinions about private schools are given in Graphic 3. Graphic 3 includes four categories and 129 codes.

Graphic 3: Teachers' negative opinions about private schools
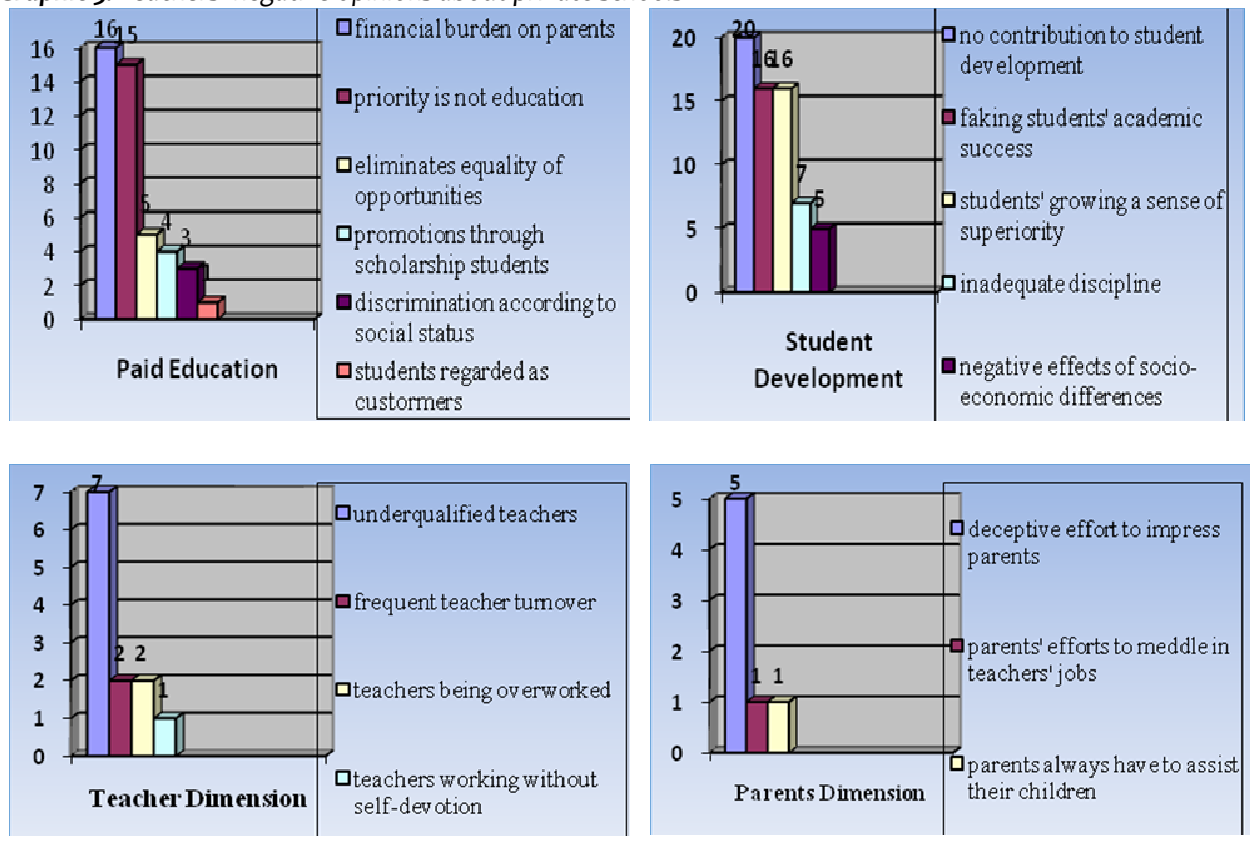

According to Graphic 3, paid education and student development are notable categories in teachers' negative opinions about private schools. financial burdens on parents and priority is not education under paid education category; no contribution to student development and faking students' academic success under student development category; underqualified teachers and frequent teacher turnover under teacher dimension category; deceptive efforts to impress parents under parents dimension category are some of the highlighted views.

Some of the remarks by the participants are below: 
"You spare too much money for private schools but you don't get what you expect fully. If you care for your child, you can develop him / her in different ways with that money. Different courses and book can do the same. That's why, I don't need private schools" (T12).

"Private schools are inflating the marks of students. Even an unsuccessful students can pass the exams with high scores" (T48).

Teachers' suggestions on private schools are shown in Graphic 4. Graphic 4 includes one category and 48 codes.

Graphic 4: Teachers' suggestions on private schools

\begin{tabular}{|c|c|}
\hline \multirow{2}{*}{1211} & "the standards of public school should be improved to catch up with priv ate school \\
\hline & "children should be send to private schools whennecessary \\
\hline \multirow[t]{2}{*}{10} & Whildren should be send to a private school when in high school or university \\
\hline & "private schools arenot necessary, parents should monitor theirpupils' progress \\
\hline 8 & "private schools to be sent should be selected carefully \\
\hline \multirow{2}{*}{6} & "there should be free education for each citizen \\
\hline & whe primary concern of private schools should be education, not business \\
\hline \multirow{2}{*}{4} & Public school should have more social activities \\
\hline & "public schools should be success-oriented, not curriculum-oriented \\
\hline \multirow[t]{2}{*}{2} & "private schools should have more disciplinary environment \\
\hline & "the ministry should inspect private schools \\
\hline \multirow[t]{2}{*}{0} & "private schools fee should be affordable \\
\hline & "unnecessary procedures in public schools should be reduced \\
\hline
\end{tabular}

Graphic 4 highlights that public schools' standards should be as high as private schools, children should be sent to private schools when necessary, children should be sent to private schools when they are at high school or university, private schools are not necessary, parents should monitor their pupils' progress, and private schools should be selected carefully.

Some of the remarks by the participants are below:

"If the state can improve physical conditions in its own schools and can make them wellequipped, public schools will be much more successful than private schools" (T8).

"Private schools hold a business mentality. So, they should be run prioritising education, not with business mentality. In addition, teacher quality in private schools should be improved" (T22).

Administrators' opinions on sending their children to private schools are given in Graphic 5 . Graphic 5 includes six categories and 86 codes. 
Graphic 5: Administrators' opinions on sending their children to private schools

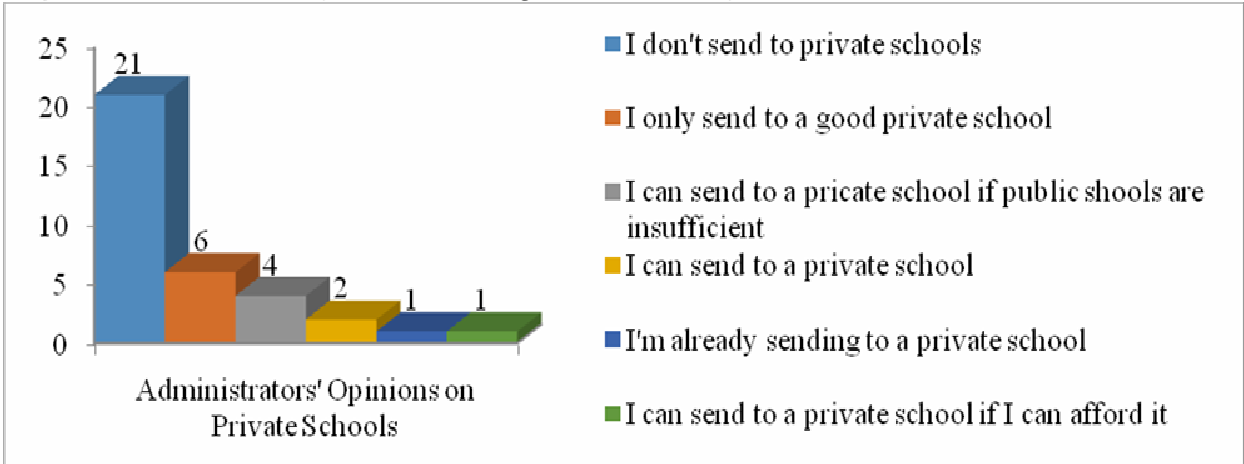

Graphic 5 shows that more than half of the administrators stated that they would not send their children to private schools. This number is higher than that of teachers. This might indicate that administrators could be more committed to their own schools than teachers. While 12 administrators stated that they would send their children to private schools only if some conditions were provided, only 2 administrators have already chosen private schools. Only one administrator send his child to a private school and this shows that administrators generally have negative opinions on private schools.

Administrators' positive opinions on private schools are given in Graphic 6. Graphic 6 includes four categories and 52 codes.

Graphic 6: Administrators' positive opinions on private schools
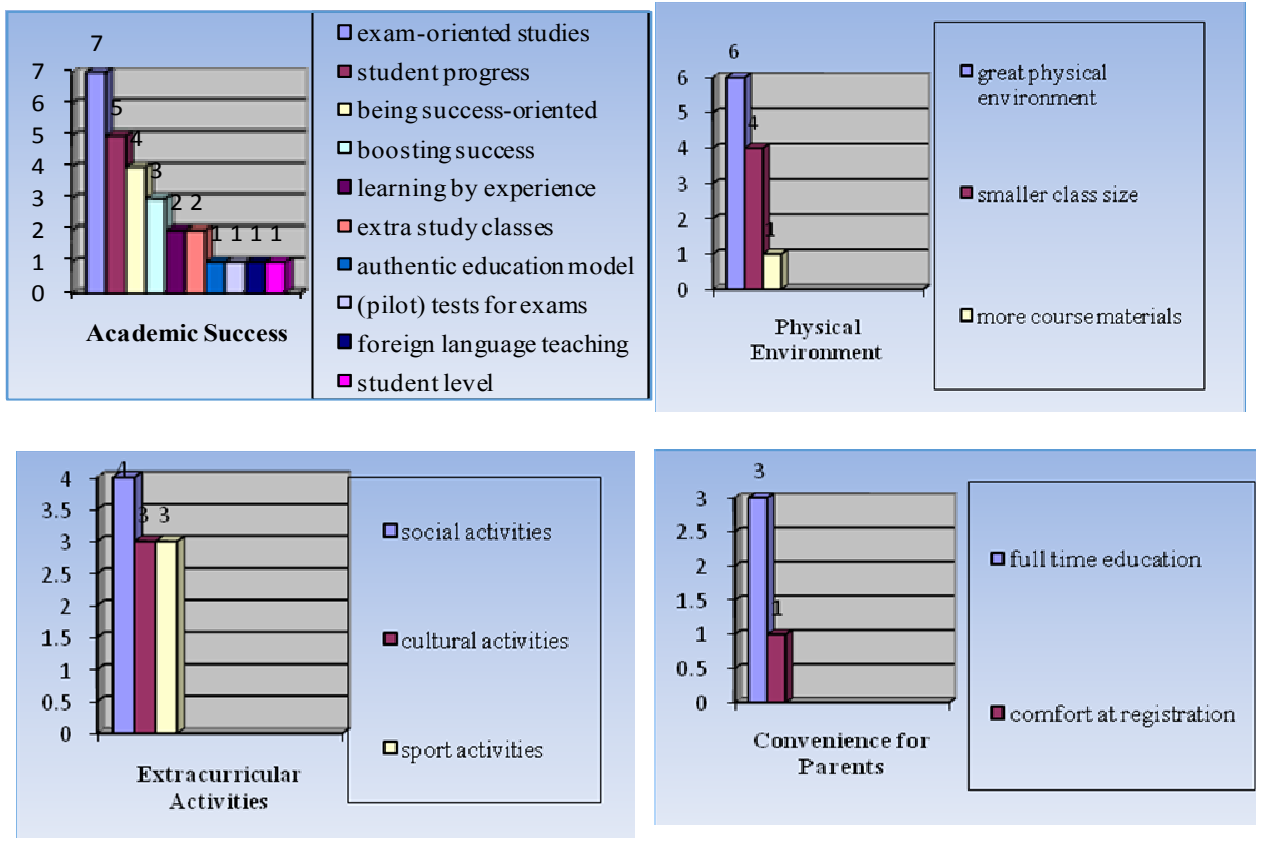
As seen in Graphic 6, academic success, physical environment, and extra-curricular activities stand out in administrators' positive opinions on private schools. success-orientation and student's progress monitoring under academic success category; great physical environment and smaller class size under physical environment category; social activities and cultural activities under extra-curricular activities; full time education under convenience for parents category are emphasized.

Some of the remarks by the participants are below;

"If the students is successful, he/she can get much better at a private school. I think especially the children whose parents both work mainly are sent to private schools. They have advantages as they can adopt an exam-oriented approach because they do not have to follow a specific curriculum" (A27).

"Private schools operate like private teaching institutions. They can make the best of students for the current exams. They take their work seriously, and they do everything by making performance and success their priority" (A24).

Administrators' negative opinions are given in Graphic 7. Graphic 7 includes 4 categories and 81 codes.

Graphic 7: Administrators' negative opinions on private schools
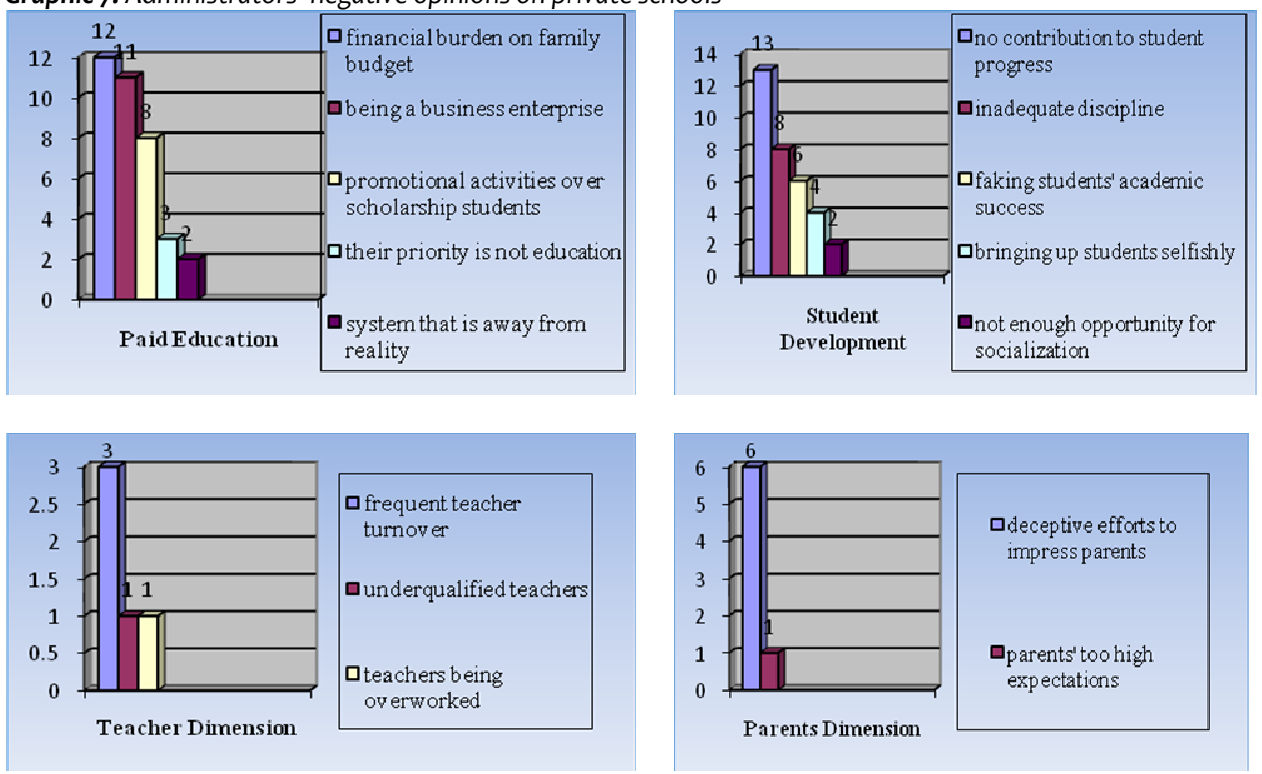

In graphic 7, it is pointed out that paid education, student progress, and teacher dimension categories are emphasized in administrators' negative opinion on private schools. Financial burden on parents and being a business corporation under paid education category; no contribution to student progress and inadequate discipline under student progress category; frequent teacher turnover and underqualified teachers under teacher dimension category; deceptive efforts to impress parents under parents dimension category are highlighted views. 
Some of the remarks by the participants are below:

"I'm in the opinion that private schools' priority is the business and education. I believe that they just implement a system which is away from reality by ingratiating themselves with parents with illusive activities" (A6).

"Private schools' teaching staff are constantly changing. I have never seen private schools' contribution to an academically low student" (A30).

Administrators' suggestions on private schools are given in Graphic 8. Graphic 8 includes one category and 25 codes.

Graphic 8: Administrators' suggestions on private schools

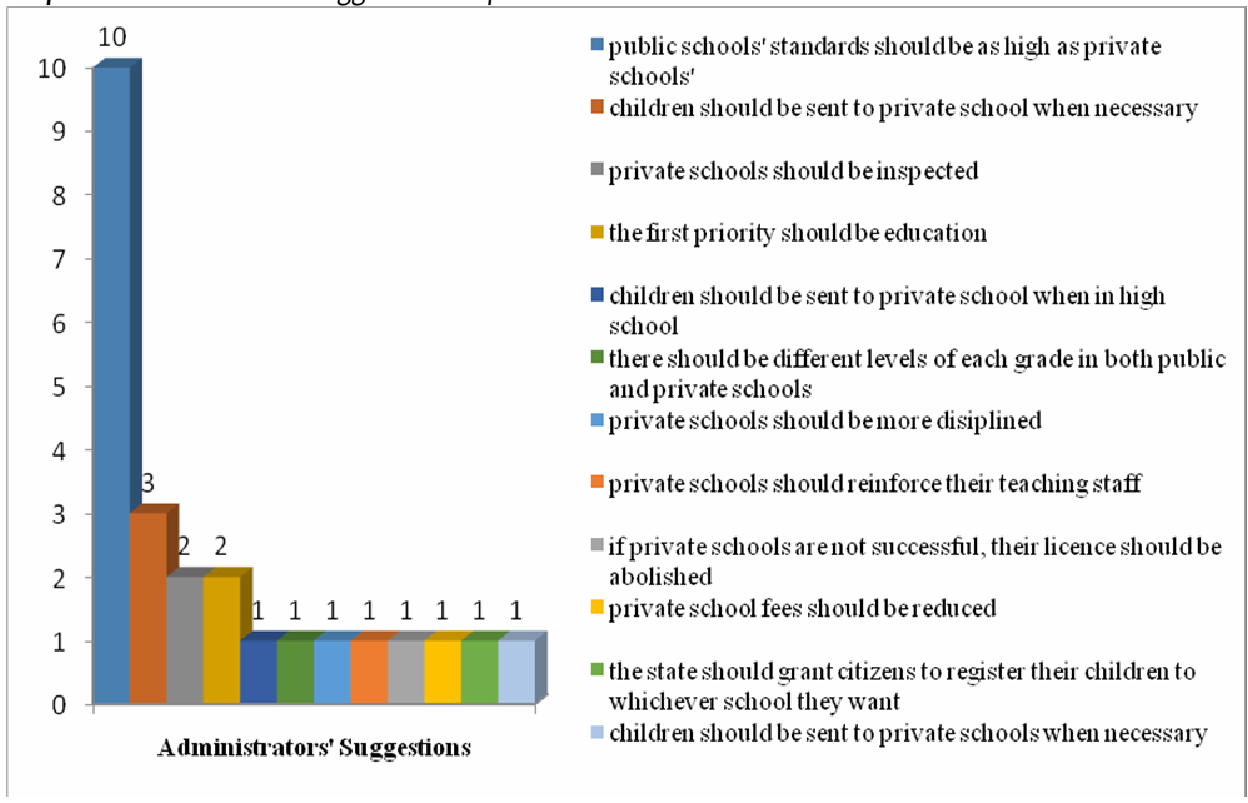

According to Graphic 8, the views which draw the attention are, public schools' standards should be as high as private schools', children should be sent to private schools when necessary, private schools should be inspected, the first priority should be education.

Some of the remarks by the participants are below:

"I think the money spent on private schools is a loss. The money can be spent for other things to help to improve the students' progress" (A4).

"Private schools can only be preferable if they reinforce their teaching staff, become more disciplined and stop letting their students cut corners" (A30). 


\section{CONCLUSION AND DISCUSSION}

According to the research findings, half of the teachers and more than half of the administrators (60\%) have stated that they wouldn't send their children to private schools. $19,7 \%$ of teachers and $5,7 \%$ of administrators have expressed that they would send their children to private schools. Furthermore, $10,4 \%$ of teachers and $2,8 \%$ of administrators have stated that they are already sending their children to private schools. Other views have been distributed considering certain conditions to send children to private schools. Similarly, the participants have declared a total of (f:185) positive opinions about private schools while there have been a total of ( $f: 210)$ negative opinions about them. The findings indicate that the participants are reluctant to send their children to private schools and they have more negative opinions about private schools.

Studies conducted about private schools suggest that as a result of the demands on private schools, the numbers of private schools is increasing (Bedi and Garg, 2000; Arslan, Satici and Kuru, 2006; Chudgar and Quin, 2012; Deeba and Perveen, 2013; Thapa, 2013; Naradowski and Moschetti, 2015; Alpaykut, 2017; Ozdemir and Tuysuz, 2017; Onaran, 2018). Nevertheless, the main reasons of the negative opinions are; according to the participants opinions, their family economy cannot cover the costs of private schools, private schools do not contribute to students' progress, and teachers at private schools are not qualified enough. However, the participants being educationists might lead to this situation. In an effort to support this idea, Kulaksizoglu, Cakar and Dilmac (1999) found out in their studies which included adults from different occupations that a significant number of adults did not have negative prejudice against private schools, but they had positive attitudes towards them.

Among positive opinions of teachers and administrators about private schools, academic success, physical environment, student progress, and extra-curricular activities are featured. Mainly highlighted opinions in these categories are; students' progress monitoring, foreign language teaching, physical facilities, class size, social and sport activities, counselling services, full time education, and exam-oriented studies. According to OECD (2012) PISA results, the schools which are administered privately possess more autonomy, better resources, and are more inclined to show better performance in PISA reading scale when compared to those administered by states.

In the related literature, it is pointed out that this topic has been covered within the context of private school selection of parents, and their expectations from private schools. The research results about the selection of private schools also reveal the advantages of private schools and parents' expectations from private schools. These results support the findings of this study. Furthermore, the quality of education, culture-faith factor, economical factors and service quality Uysal (2017); qualified teaching staff Arslan and Ozpinar (2008); the opportunity to learn foreign languages, full time education, computer education, regular diet, good school bus services Akhan (2009); smaller class size, students' convenience of auditory and heating facilities Alpaykut (2017); communication processes, art, sport, social and cultural activities Pulat (2019); personnel skills, facilities, technology and transportation Malik, Mushtaq, Jaswal and Malik (2015); raising a successful individual, developing personality, getting into university Hesapcioglu and Nohutcu (1999); the distance of school from home, school performance, school environment and syllabus Yaacob, Osman and Bachok (2015) have been refered within the context of private schools. 
The participants have particularly stated that extracurricular activities and social activities are included in private schools, and thus offering students a rich environment. About extracurricular activities which are as important as students' academic success, Annu and Sunita (2013) have concluded in a study conducted in a private school that yoga, horse-riding, sport activities, dance, music, indoor and outdoor activities are contributing positively to students overall development in private schools. This suggests that students who attend extracurricular activities generally have higher grade-point average, less absence from class, and more school commitment. This study of Annu and Sunita (2013) supports the participants' positive opinions about private schools.

Considering the research findings, it is noticed that the participants tend to compare public and private schools. The studies that examine and compare private and public schools according to different variables in the literature have put forward the positive sides and strengths of private schools, and thereby they support the findings of this research. In this regard, teachers working for private schools; have lower level of alienation Eryilmaz and Burgaz (2011); are more effective in specified dimensions of effective schools Arslan, Satici and Kuru (2006); have higher participative leadership and higher level of organizational commitment Aslan and Bakir (2014); have a higher level of job satisfaction Tasdan and Tiryaki (2010); have a higher level of school culture Yavuz and Yilmaz (2012); have a higher organizational culture Arslan, Satici and Kuru (2007); give more importance to values education Oksuz (2018); have a higher level of proactive behaviours Aslan (2019) than teachers working for public schools.

Likewise, it has been determined that students studying in private schools; have a higher level of achieving cognitive objectives Bay and Tugluk (2004); have a better performance in labour market Bedi and Garg (200); are more successful in international exams OECD (2013); have a higher level of athletic success Cevik (2005); are academically more successful Chudgar and Quin (2012), Alderman, Orazem and Paterno (2001), Cavalcanti, Guimaraes and Sampaio (2010), Iqbal (2012) than students studying in public schools.

The negative opinions of teachers and administrators on private schools are mainly about the categories of paid education, student development and teacher dimension. The frequently highligted opinions under these categories have been financial burden on parents, not enough contribution to students' development, faking students' academic success, offering successful students scholarship and promotions over them, inadequate discipline, underqualified teachers, deceptive efforts to impress parents. It has been found out that the participants share common opinions.

Studies show that students studying at private schools are in middle and upper class of the society (Keskin and Turna, 2010; Dearden, Ryan and Sibieta 2010; Cowen, 2010; Murnane and Reardon, 2018; Bellei, 2007; Valassi, 2009; Hall and Nattinger, 2012). Figlio and Stone (2001) have discovered that highly gifted students, and students whose families have high income and have higher education prefer private schools. Similarly, according to OECD (2012) in most of the countries and economies participating PISA, students attending private schools are more advantageous comparing with public schools in terms of their average socio-economic backgrounds. With this regard, as Uygun (2003) stated, private schools are widely criticized over breaking the equal opportunity in education. A high quality private school does bring a financial burden on parents; however, the findings of Chudgar and Quın (2012) suggests that 
low-cost private schools do not perform better than public schools academically; that's to say, they bring financial burden in exchange for quality services.

There are some studies supporting the ideas of the participants about the qualities of private school teachers and their problems. According to Erakkus, Basoren and Abimbola (2016), some schools pay too low salaries to teachers. Their working hours are too long. Although private schools provide various in-service trainings, few schools let their teachers to get a post-graduate degree. Hesapcioglu and Nohutcu (1999) state that in spite of the fact that parents give utmost importance to teacher quality, private schools still do not pay enough attention to their teacher recruitment. Shabbir and Wei (2015) claim that teachers working for private schools are faced with the problems such as low salaries, job insecurity, long working hours, and short vacation times. Moreover, Onaran (2018) points out that private school managements have teachers signed the contracts with low salaries by threatening them to cancel their contracts.

The participants express that they encounter deceptive efforts to impress parents. This situation causes many ethical problems. According to Garipoglu (2015), it is claimed that private schools in Turkey apply various unethical methods for customer retention and make more money. The study suggests that unethical efforts performed by private schools are; shadow programs, double report cards, misleading lists and announcements, student transfers from other schools, expelling students from school or misleading students branches, and students stratification among different student groups.

Cimen and Karadag (2019) have pointed out some of the unethical behaviours; for instance, private school principals do not treat teachers with the principle of equality, and there are some efforts among teachers to reveal one another's faults, and other efforts such selfpromotion of teachers. Another ethical problem is that, as stated by Bertola, Checchi and Oppedisano (2007), Valassi (2009), private schools enrol students through selection and promote their schools over these successful students.

Considering the suggestions of teachers and administrators about private schools, public school standards should be raised as high as private schools, students should be sent to private schools when they are at high school or university, private schools are not necessary; the parent should monitor their own kids' progress, the very first priority should be education, private school should be inspected, and the private school to send the children should be chosen carefully are some the remarkable opinions. The participants' opinions are quite similar. The suggestions on governmental incentives to private schools and regulations referring to parents' expectations are notable in the literature. About governmental incentives, Bayram (2015) suggests that the common aspect of education should be improved, and there should be provided quality education for each level; Uygun (2003) suggests that the governmental incentives to private schools should be raised, and they should be kept under strict control and inspection; Watkıns (2006) suggests that there should be provided financial support to students attending private schools.

In the literature, suggestions on parents' expectations are discussed the most. In this respect, it has been suggested that Dulger and Acar (2017), processes affecting school's service quality and systematically informing parents about the performance and service quality results; Arcan (2006), the involvement of parents into the scope of school counselling services performed for students' academic failures; Uysal (2017), improving school's education quality, physical 
structure, sanitation, security and school bus services, operational aspects, the quality of communication in accordance with parents' opinions; McTighe (2004), private schools should inform parents furthers and they should be accountable; Bellei (2007), creating a national student learning system aiming informing parents about school quality; Garipagaoglu (2015), transparent administration of schools in order to eliminate unethical efforts for manipulating parents in schools, formulation of educational policies in order to eliminate unethical practices. Besides, Hesapcioglu and Nohutcu (1999) state that it is important to act responsibly while selecting teachers; Malik, Mushtaq, Jaswal and Malik (2015) recommend that private schools should work more productively by forming a competitive and distinctive images of themselves.

The participants of this study have made suggestions on behalf of their identities of both being educationists and parents. The participants' suggestions and the findings of the literature support one another. Apart from these, it can be suggested within the scope of this research that although private schools are business corporations, their initial priority should be education, specific to Turkey, the governmental incentives which were granted between the years 2014-2018 should be proceeded, teachers' personal benefits and rights should be improved, and it can also be suggested that the misperception of regarding students as customers should be abandoned.

\section{REFERENCES}

Akhan, A., (2009). Velilerin ozel ilkogretim okullarindan beklentileri ve beklentilerinin karsilanma duzeyleri (Istanbul avrupa yakasi ornegi). Yuksek lisans tezi, Yeditepe Universitesi, Istanbul.

Alderman, H., Orazem, P. F., \& Paterno, E. M. (2001). School quality, school cost, and the public/private school choices of low-income households in Pakistan. Journal of Human resources, 304-326.

Alderman, S. (2017). Ogrenci velilerinin ozel okullardan memnuniyet duzeylerinin yapisal esitlik modeli ile degerlendirilmesi. Dokuz Eylul Universitesi Iktisadi Idari Bilimler Fakultesi Dergisi, 32(2), 355-368.

Altay, M. (2018). Ailelerin ozel okul tercihlerinde marka deger bilesenlerine etkisi uzerine bir arastirma. Yuksek lisans tezi, Istanbul Ticaret Universitesi, Istanbul.

Annu, S., \& Sunita, M. (2013). Impact of extracurricular activities on students in private school of lucknow district. International Journal of Humanities and Social Science Invention, 2(6), 2319-7714.

Arcan, K. (2006). Ozel okullara giden lise duzeyindeki ergenlerin, akademik basarıları ile algıladıkları anne-baba tutumları arasındaki iliskilerin incelenmesi. Yuksek lisans tezi, Maltepe Universitesi, Sosyal Bilimler Enstitusu, Istanbul.

Arslan, H., Kuru, M., \& Satici, A. (2010). Devlet ve ozel ilkogretim okullarının etkililiginin arastirilmasi. Egitim ve Bilim, 32(142), 15-25.

Arslan, H., Satici, A., \& Kuru, M. (2007). Resmi ve ozel ilkogretim okullarinin kultur ve etkililik duzeylerinin karsilastirilmasi. Kuram ve Uygulamada Egitim Yonetimi, 51(51), 371-394.

Arslan, S. \& Ozpınar, I. (2008). Ogretmen nitelikleri: ilkogretim programlarinin beklentileri ve egitim fakultelerinin kazandirdiklari. Necatibey Egitim Fakultesi Elektronik Fen ve Matematik Egitimi Dergisi, 2(1), 38-63.

Aslan, E. A. (2019) Turkiye'de ozel okullasma. Bitlis Eren Universitesi Sosyal Bilimler Enstitusu Dergisi, 8(1), 263-276. 
Aslan, M., \& Bakir, A. (2014). Resmi ve ozel okul ogretmenlerinin paylasilan liderlige iliskin gorusleri. Inonu Universitesi Egitim Fakultesi Dergisi, 15(1), 121-142. DOI: 10.17679/iuefd.75431.

Bay, E., \& Tugluk, M. N. (2004. Resmi ve ozel ilkogretim okullari ogrenci basarilarinin karsilastirilmasi. Ataturk Universitesi Sosyal Bilimler Enstitusu Dergisi, 4(2), $135-153$.

Bayram, A. (2015) Ozel okul sayilari ve kamu yatirimlarina iliskin gostergelerin dusundurdukleri. Elestirel Pedogoji, 7(37), 65-70.

Bedi, A. S., \& Garg, A. (2000). The effectiveness of private versus public schools: The case of Indonesia. Journal of Development Economics, 61(2), 463-494.

Bellei, C. (2005). The private-public school controversy: The case of Chile. In Conference on Mobilizing the Private Sector for Public Education, 5(6), 1-11.

Bertola, G., Checchi, D. ve Oppedisano, V. (2007). Private school quality in Italy. Giornale degli Economisti e Annali di Economia, 66(3), 375-400.

Bingolbali, N. (2018). Ozel okullarda egitim alanında yasanan problemler ve cozum onerileri. Yuksek lisans tezi, Istanbul Gelisim Universitesi Sosyal Bilimler Enstitusu, Istanbul.

Boerema, A.J. (2006) An analysis of private school mission statements. Peabody Journal of Education, 81(1), 180-202, DOI: 10.1207/S15327930pje8101_8

Butler, T. \& Zanten, A. (2007). School choice: a European perspective. Journal of Education Policy, 22(1), 1-5. DOI: 10.1080/02680930601065692.

Buyukozturk, S. (2005). Anket gelistirme. Turk Egitim Bilimleri Dergisi, 3(2), 133-151.

Cankaya, I., Gun, C., \& Koleji, U. K. (2016). Okul merkezli yonetime iliskin ozel okul yoneticilerinin gorusleri. Egitim ve Ogretim Arastirmalari Dergisi, 5, 38-43.

Carpenter, D. M. \& Kafer, K. (2012) A history of private school choice. Peabody Journal of Education, 87(3), 336-350. DOI: 10.1080/0161956X.2012.679587

Cavalcanti, T., Guimaraes, J., \& Sampaio, B. (2010). Barriers to skill acquisition in Brazil: Public and private school students performance in a public university entrance exam. The Quarterly Review of Economics and Finance, 50(4), 395-407.

Celebi, N. (2009). Resmi ve ozel ilkogretim kurumlarinda calisan ogretmen ve yoneticilerin disiplin sorunlari ve odullendirme uygulamalari. M.U. Ataturk Egitim Fakultesi Egitim Bilimleri Dergisi 29, 75-100.

Cevik, S. (2005). Ozel okul ve kamu okullarinin spora ayirdiklari finansman ve sportif basarılarinin karsilastirilmas. Yuksek Lisans tezi, Marmara Universitesi Saglik Bilimleri Fakultesi, Istanbul.

Chakrabarti, R. (2007). Can increasing private school participation and monetary loss in a voucher program affect public school performance? Evidence from Milwaukee. Evidence from Milwaukee (September 2007). FRB of New York Staff Report, (300).

Chudgar, A., \& Quin, E. (2012). Relationship between private schooling and achievement: Results from rural and urban India. Economics of Education Review, 31(4), 376-390.

Cimen, B., \& Karadag, E. (2019). Ozel okul mudurlerinin etik davranislari uzerine bir arastirma. Is Ahlaki Dergisi, 171, 171-201. DOI: 10.12711/tjbe.2019.12.1.0125.

Cobanoglu, A. (2011). Resmi ve ozel ilkogretim okullarının okul imajinin ogretmen ve veli goruslerine gore degerlendirilmesi. Yuksek Lisans tezi, Marmara universitesi egitim bilimleri enstitusu, istanbul.

Cowen, J. (2010). Who chooses, who refuses? Learning more from students who decline private school vouchers. American Journal of Education, 117(1), 1-24.

Creswel J. W. (2013). Nitel arastırma yontemleri. (Çev ed:M. Bütün- S.B. Demir). Ankara: Siyasal Kitabevi. 
Dearden, L. Ryan, C. and Sibieta, L. (2010) : What determines private school choice? A comparison between the UK and Australia, IFS Working Papers, No. 10,22, Institute for Fiscal Studies (IFS), London.

Deeba, F. C., \& Perveen, U. (2013). A study of teachers workload and job satisfaction in public and private schools at secondary level in lahore city Pakistan. Asian Journal of Social Sciences \& Humanities, 2(1), 202-214.

Dronkers, J. \& Robert, P. (2008) School choice in the light of the effectiveness differences of various types of public and private schools in 19 OECD countries. Journal of School Choice, 2(3), 260-301. DOI: 10.1080/15582150802371499.

Dulger, G., \& Acar, O. K. (2017). Ozel okullarda kurumsal itibar algisi: okul paydaslari uzerinde bir arastirma ve model onerisi- Mehmet Akif Ersoy Universitesi Sosyal Bilimler Enstitusu Dergisi, 9(22), 259-277.

Erakkus, O., Basoren, M. T., \& Abimbola, O. (2016). Ozel okul yoneticilerinin ogretmen egitiminden beklentileri uzerine nitel bir arastırma. Karaelmas Egitim Bilimleri Dergisi, 4(2), 104-115.

Eryilmaz, A., \& Burgaz, B. (2011). Ozel ve resmi lise ogretmenlerinin orgutsel yabancilasma duzeyleri. Egitim ve Bilim, 36(161), 271-286.

Ferreyra, M. M. (2007). Estimating the effects of private school vouchers in multidistrict economies. American Economic Review, 97(3), 789-817.

Figlio, D. N., \& Stone, J. A. (2001). Can public policy affect private school cream skimming?. Journal of Urban Economics, 49(2), 240-266.

Garipagaoglu, B. C. (2015). Ozel okul sektoru ve etik disi basari muhendisligi uygulamalari. Journal of Kirsehir Education Faculty, 16(3), 181-200.

Hall, J. C., \& Nattinger, M. C. (2012). Determinants of private school attendance: evidence from Wisconsin school districts. International Advances in Economic Research, 18(2), 245-246.

Hesapcioglu, M., \& Nohutcu, A. (1999). Velilerin ozel okul tercihlerini etkileyen faktorler ve ozel okullarin reklam stratejileri. Marmara Universitesi Ataturk Egitim Fakultesi Egitim Bilimleri Dergisi, 11(11), 183-202.

Ilgar, L. (2014). Ozel okul ve devlet okulunda gorev yapmis sinif ogretmenlerinin sinif yonetimindeki farkliliklara iliskin gorusleri: nitel bir calisma. HAYEF Journal of Education, 11(2), 259-285.

Iqbal, M. (2012). Public versus private secondary schools: A qualitative comparison. Journal of Research and Reflections in Education, 6(1), 40-49.

Keskin, H. D., \& Turna, G. B. (2010). Ailelerin devlet ya da ozel okul tercihlerini etkileyen faktorler Rize ornegi. Cukurova Universitesi Sosyal Bilimler Enstitusu Dergisi, 19(2), 411426.

Kolbasi, E. (2019). Duygusal emek ve is tatmini arasındaki iliski: Denizli'deki ozel okul ogretmenleri uzerinde bir arastirma. Yuksek lisans tezi, Pamukkale Universitesi Sosyal Bilimler Enstitusu, Denizli.

Kulaksizoglu, A., Cakar, M., \& Dilmac, B. (1999). Turkiye'de ve dunyada ozel okulların yapisi ve isleyisi. Marmara Universitesi Ataturk Egitim Fakultesi Egitim Bilimleri Dergisi, 11(11), 219232.

Malik, S. A., Mushtaq, A., Jaswal, L. H., \& Malik, S. A. (2015). Survey on marketing tactics used to build private school image and increase parents' loyalty. International Journal of Management in Education, 9(2), 180-199.

McTighe, J. (2005). Private school accountability. Journal of Education, 185(3), 51-59.

MEB (2019). Milli Egitim Istatistikleri 2018-2019. Ankara: Strateji gelistirme Baskanligi

Murnane, R. J., \& Reardon, S. F. (2018). Long-term trends in private school enrollments by family income. AERA Open, 4(1), 1,24. DOI: 2332858417751355. 
Narayan, V. (2010). The private and the public in school education. Economic and Political Weekly, 45(6), 23-26.

OECD (2012), Public and Private Schools: How Management and Funding Relate to their Socioeconomic Profile, OECD Publishing. http://dx.doi.org/10.1787/ 9789264175006-

OECD (2013), PISA 2012 Results: What Makes Schools Successful? Resources, Policies and Practices (Volume IV), PISA, OECD Publishing.

Oksuz, H. I. (2018). Degerler egitiminde kamu kurumlari mi ozel ogretim kurumlari mi?. HAYEF Journal of Education, 15(1), 97-120.

Onaran, M. A.(2018). Ozel okullarda calisan tarih ogretmenlerinin ozel okul yonetimi ile ilgili yasadiklari sorunlar ve cozum onerileri. Inonu Universitesi Egitim Bilimleri Enstitusu Dergisi, 5(10), 49-67.

Ozdemir, A., \& Tuysuz, F. (2017). Ozel okul yatirimlari icin Turkiye'deki 81 ilin cok kriterli karar verme yontemleri ile stratejik analizi. Marmara Universitesi Ataturk Egitim Fakultesi Egitim Bilimleri Dergisi, 45(45), 93-114.

Paker, N., \& Yarimoglu, E. K. (2015). Ozel ilkokullarin internet sitelerinin icerik analizi yontemi ile incelenmesi. Karabuk Universitesi Sosyal Bilimler Enstitusu Dergisi, 5(2), 269-284.

Pulat, A. (2019). Ilkokul velilerinin ozel okul tercihlerine etki eden faktorlerin incelenmesi. Yuksek lisans tezi, Istanbul Sabahattin Zaim Universitesi, Sosyal Bilimler Enstitusu, Istanbul.

Sahin, B. (2012). Metodoloji. Bilimsel Arastirma Yontemleri (Ed: A. Tanriogen). Ankara: Ani.

Sakellariou, C. (2017) Private or public school advantage? Evidence from 40 countries using PISA 2012-Mathematics. Applied Economics, 49(29), 2875-2892, DOI: 10.1080/00036846. 2016.1248361.

Sander, W. (2015) Private school choice in the Chicago Metropolitan Area. Journal of School Choice, 9(2), 267-281. DOI: 10.1080/15582159.2015.1028863.

Shabbir, M., \& Wei, S. (2015). Job satisfaction variance among public and private school teachers, case of Pakistan Administrative Kashmir. Mediterranean Journal of Social Sciences, 6(4), 574-574.

Tasdan, M., \& Tiryaki, E. (2010). Ozel ve devlet ilkogretim okulu ogretmenlerinin is doyumu duzeylerinin karsilastirilmasi. Egitim ve Bilim, 33(147), 54-70.

Thapa, A. (2013). Does private school competition improve public school performance? The case of Nepal. International Journal of Educational Development, 33(4), 358-366.

Uygun, S. (2003). Turkiye' de dunden bugune ozel okullara bir bakis (gelisim ve etkileri). Ankara Universitesi Egitim Bilimleri Fakultesi Dergisi, 36(1), 107-120.

Uysal, B. S. (2017). Velilerin ozel okul tercih nedenlerinin incelenmesi. Yuksek lisans tezi. Marmara Universitesi Egitim Bilimleri Enstitusu, Istanbul.

Valassi, D. (2009). Choosing a private school in the Greek education market: a multidimensional procedure. Atelier, 6, 13-14.

Vandenberghe, V., \& Robin, S. (2004). Evaluating the effectiveness of private education across countries: a comparison of methods. Labour economics, 11(4), 487-506.

Watkins, S. (2006). Are public or private schools doing better? How the NCES study is being misinterpreted. Backgrounder No. 1968. Heritage Foundation.

Yaacob, N. A., Osman, M. M., \& Bachok, S. (2015). An assessment of factors influencing parents' decision making when choosing a private school for their children: a case study of Selangor, Malaysia: for sustainable human capital. Procedia environmental sciences, 28, 406-417.

Yavuz, Y., \& Yilmaz, E. (2012). Resmi ve ozel ilkogretim okullarinin okul kulturu uzerine ogretmen ve ogrenci gorusleri. International Journal of New Trends in Arts, Sports \& Science Education (IJTASE), 1(3), 76-90. 
Yildirim, A. \& Simsek, H. (2011). Sosyal bilimlerde nitel arastırma yontemleri. (8. Baskı). Ankara: Seckin.

\section{Biographical notes:}

Soner DOĞAN is an Associate Professor in Education Faculty of Sivas Cumhuriyet University, Sivas, Turkey. His research interests include leadership, school climate, conflict management, and school vandalism. 